\title{
Proving Montessori: Identity and Dilemmas in a Montessori Teacher's Lived Experience
}

\author{
Olivia Christensen \\ University of Minnesota \\ Keywords: Montessori, teacher preparation, early childhood, critical discourse analysis, phenomenology
}

\begin{abstract}
This phenomenological case study was conducted to better understand the experience of a Montessori teacher in a leadership role. A veteran Montessori teacher, newly hired by an established Montessori preschool, was interviewed over the course of her first year in the position. A critical discourse analysis revealed multiple social identities that contributed to her desire, and ability, to be what she felt was an authentic Montessori educator. While some of these discourses and social identities aligned, some did not, creating ideational dilemmas that affected her work, relationships, and personal identity. The findings suggest that current Montessori discourse excludes important characteristics of the teacher-lived experience. Acknowledging and discussing the social challenges Montessori teachers face is a necessary addition to teacher preparation, teacher support systems, and Montessori leadership decisions.
\end{abstract}

Maria Montessori prescribed a form of mental, emotional, and even spiritual teacher preparation used in teacher education to this day. This preparation develops skills that are essential to creating a quality Montessori classroom environment. However, teachers' duties and responsibilities have evolved over the years, expanding beyond the classroom walls. Teachers, including Montessori Early Childhood teachers, are frequently expected to develop and maintain harmonious parent-teacher relationships, conduct parentwide and even community-wide education events, and promote school philosophy. While they work to embody what it means to be a Montessori teacher in the classroom, they may be confronted with differing and even contradictory social beliefs, rules, and identities from the greater social community. These experiences can be challenging and discouraging for both novice and veteran Montessori educators.

Because of these added responsibilities, a better understanding of the difficulties Montessori teachers face in this role is invaluable for both Montessori teachers and Montessori teacher education programs. Acknowledging and addressing these challenges with preservice teachers will help prepare them for their future work, fostering well-informed and confident teacher-leaders. Additionally, insight into potential challenges and successes between a school community and Montessori pedagogy is necessary not only to help classroom teachers but also to inform Montessori leaders about how to improve and strengthen the Montessori Method of education as its use in schools continues to grow.

As a former Montessori preschool teacher, I experienced the difficulty of effectively sharing Montessori theory with others and the pressure to consistently represent the "true Montessorian." Because I had incorporated Montessori so deeply into my personal identity, these challenges were not only frustrating but also often emotional, affecting my attitude toward my day-to-day work. As a doctoral student of teacher education, I used these personal experiences to guide my research process as I sought to better understand the experience of being a lead Montessori teacher. 
To this end, I conducted several phenomenological interviews with a veteran Montessori teacher. The following analysis is focused on a section of one interview session. My research question was: How does a teacher characterize her experience of proving Montessori philosophy to a small preschool community? The following analysis sheds light on the push and pull between multiple identities and discourses that were a part of this experience.

\section{Literature Review}

An important part of educational research and teacher education is understanding the development of a teacher's identity, including the challenges and obstacles that may affect a teacher's practice. The literature reviewed provides further understanding of Montessori theory of the prepared adult, its current challenges, and recent research and discussion regarding teacher experience and identity.

To become a true Montessori educator, the adult must embark on not only a unique form of educational training, but also what Dr. Montessori (1967b) called spiritual preparation. She wrote, "The educator must not imagine that he can prepare himself for his office merely by study, by becoming a man of culture. He must before all else cultivate in himself certain aptitude of a moral order" (Montessori, 1967b, p. 107). She continued her instructions, describing steps for inward preparation that include critical selfreflection, objective observations, and a new understanding of child psychology. The emphasis on personal preparation in teacher education and teacher practice is unique to the Montessori Method (Lillard, 2005) and is often referred to as an experience of personal transformation (Cossentino, 2009; Lillard, 2005). This process has evolved into a belief in the essential Montessori teacher, a commitment to a certain way of being - a feeling of responsibility, and ability, to fulfill revered philosophical principles (Malm, 2004). This lived experience creates an identity of not simply a teacher, but more specifically, a Montessori teacher (Malm, 2004). While the transformation focuses on inward reflection and change, generating a new or additional self-identity (i.e., self-concept and emotional identification with self-descriptions), a Montessori teacher also takes up a new social identity equipped with specific characteristics and expectations to be fulfilled and maintained (Barker, 2012).

The vast majority, if not all, of Dr. Montessori's suggestions and directions for teacher spiritual preparation focus on the teacher's presence and identity within the classroom, working with the children. Today, the duties of any teacher, including an Early Childhood Montessori teacher, extend beyond the classroom walls. Creating and sustaining parent-teacher relationships, practicing culturally relevant pedagogy, navigating early childhood education rules and regulations, and representing Montessori education for school promotion and marketing purposes are just some of the additional demands placed on Montessori educators. Research has suggested that, although these duties are crucial for effective early education (Bartik, 2014; Copple \& Bredekamp, 2009; Graue, Kroeger, \& Prager, 2001), their corresponding values and belief systems harbor the potential to create instances of ideational conflicts (Cuban, 1992; HallKenyon, Bullough, MacKay, \& Marshall, 2014; Helsing, 2007; Sumsion, 2002), pitting one social identity against another. These conflicts can be referred to as dilemmas, meaning "conflict-filled situations that require choices because competing, highly prized values cannot be satisfied" (Cuban, 1992, p. 6). Dilemmas occur frequently in teaching because of the varied developmental expectations, educational policies, teacher beliefs, and social values, among others, existent in the early childhood educational system (Helsing, 2007). Dilemmas are particularly challenging because they often require teachers to make moral choices, frequently leading to "good-enough compromises" (Cuban, 1992, p. 7) that are achieved by sacrificing part of one belief to satisfy the needs of another belief. Not only can this sacrifice be unsettling, but it can also be only a momentary fix, leaving the dilemma to be "renegotiated again and again because [it is] so deeply embedded in who we are and the practice of teaching" (Cuban, 1992, p. 7, emphasis added).

The personal nature of dilemmas can cause uncertainty in a teacher's practice (Helsing, 2007; Lampert, 1985). Uncertainty in teaching can arise from a variety of educational beliefs and expectations, as well as from the complex social and emotional requirements of teaching. This uncertainty can affect one's teaching practice and even self-identity. While a Montessori teacher may have been trained to create 
and sustain a specific identity, dilemmas create moments for critical examination of, and possible uncertainty about, the ability to fulfill such an identity and be a true Montessori teacher. Certainly, Montessori teacher preparation acknowledges the need for self-examination and the willingness to meet the needs of children and their environment in creative ways. However, with the added job responsibilities previously described come more opportunities for dilemmas and uncertainty on a greater social and philosophical level.

The current, and constant, change existent in the early childhood educational system has the potential to pose many dilemmas and instances of uncertainty in a Montessori teacher's practice. Teachers must learn to cope with and successfully navigate the evolving system (Kilgallon, Maloney, \& Lock, 2008). Although uncertainty can create opportunities to identify, address, and improve teaching practice, it is also a frequent cause of stress, frustration, and burnout (Floden \& Buchmann, 1993; Helsing, 2007). Teaching is naturally an emotional profession, perhaps particularly for Montessori teachers, for whom much internal self-preparation is an inherent part of the work. Research (Hall-Kenyon et al., 2014; Sumsion, 2002) has suggested a need for a closer look at the ways in which all early childhood teachers need support to move through dilemmas and overcome uncertainty. Therefore, identifying the types of dilemmas that may develop in a Montessori Early Childhood teacher's experience, along with their potential effects on her identity, is valuable research.

\section{Theoretical Orientation}

This paper adheres to the belief that identity is a social experience and construct (Barker, 2012; Gee, 2014). To better understand such an experience, this study followed a phenomenological approach, with the broad intention of seeking to better understand ways in which social actors "find [themselves] being in relation to the world through [their] day-to-day living" (Vagle, 2014, p. 20). Research began by pursuing not just the activities of a teacher, but rather the lived experience of being a teacher-leader. Because phenomenology is the study of how things are and how they are becoming, the phenomenon, or unit of analysis, reveals itself throughout the research process (Vagle, 2014). In this analysis, the revealed phenomenon was the experience of having to prove the value of one's identity and Montessori education to a school community.

Hermeneutic phenomenologist Max van Manen (2014) noted that the moment a phenomenon is named, it is removed from the multilayered and expansive lived experience of which it had been a part. Therefore, using an analytical approach that created opportunities to consider the multiple layers surrounding the phenomenon was helpful in focusing on "the regions where meanings and understandings originate" (van Manen, 2014, p. 26) within a lived experience. Proving the value of one's identity and system of knowledge and beliefs is a social action with broad personal and social implications. Thus, it was necessary to take up a theory of critical discourse analysis (CDA) that uses both a micro and macro lens to better understand the personal and social qualities of the phenomenon.

To answer the research question of how a teacher characterized the experience of proving Montessori philosophy to a small preschool community, I used Fairclough's (1992) theory of discourse analysis, specifically the three dimensions of analysis: (a) discursive practice (the resources used to produce the actor's discourse[s]), (b) text (the microanalysis of how this is done), and (c) social practice (why the discursive practice is the way it is and its relation to broader social practice[s]). Gee's (2014) theory of socially significant identities helped clarify how actors navigate and represent themselves in a social context. Finally, van Leeuwen's (2007) legitimation offered further insight into positionality within a community. The combination of these three approaches to CDA proved effective in better understanding the phenomenon of proving the value of one's identity and Montessori education to a school community.

Fairclough (1992) suggested that "discourse is a practice not just of representing the world, but of signifying the world, constituting and constructing the world in meaning" (p. 64). A CDA following this theory helped illuminate not merely how the phenomenon was represented, but also the identities that comprise the construction of that representation, as well as the effects of social worlds on its creation. Gee (2014) defined identity as a performance and that, "like all performances, it will not work unless at least 
some people recognize what you are and what you are doing in your performance" (p. 24). In this way, understanding a social actor's identity is important to better understanding how an actor views, reacts, and relates to an experience in the world, as well as how others in the world view, react, and relate to the actor. These interactions are what Gee described as "recognizing socially significant identities," and they create his theory of "big 'D' Discourse" (p. 25). In this research analysis, the capitalized term Discourse is used to highlight the socially meaningful identities interacting within and through the phenomenon.

Following Fairclough's instructions on CDA by exploring the messages created through discursive practice, texts, and social practices revealed not only when and how Montessori identity and its system of knowledge and beliefs were reproduced, but also when they were challenged and even contradicted, creating a dilemma and the potential for uncertainty. Analyzing these moments, or times of uncertaintywhat Fairclough refers to as "cruces" or "moments of crisis" (p. 230) - aided in discerning "the actual ways in which people deal with the problematization of practices" (p. 230), and more specifically how an actor problematizes and works through the experienced phenomenon.

Finally, van Leeuwen's (2007) categories of legitimation helped to explore the participant's positionality within a community and the ways identity was used in the experience. Van Leeuwen's (2007) theory of legitimation in discourse and communication states that legitimation is an element of discourse used to answer the question "Why?" (p. 93) Legitimation is an explanation-explicit or implicit —of why things are done or should be done a certain way. In this analysis, three of van Leeuwen's (2007) categories of legitimation were used to better explain why the subject acted in particular ways: authorization, moral evaluation, and rationalization. Analyzing how and why these three forms of legitimation occurred helped to identify not only the reasons for certain choices, but also the Discourses, identities, and knowledge systems that most influenced decisions and the experience.

Because all of these elements of discursive practice relate to the social world, they contribute to the reproduction of societal structures. However, they also can create opportunities for transformation (Fairclough, 1992). These moments of crisis require decisions that are perhaps not as expected and normed as they are during moments of calm and regularity. Exploring the factors that contributed to the development and outcome of such moments and decisions helps readers to better understand the experience of a Montessori teacher-leader and the phenomenon of proving the value of one's identity and Montessori education to a school community.

\section{Method}

\section{Participant}

Over the course of a school year, I interviewed Claire ${ }^{1}$, a Montessori teacher who had been recently hired by a small, well-established Montessori preschool. She came to the job with significant teaching experience and a firm grasp of Montessori theory and curriculum. The board was hoping to revitalize the school's use of Montessori practices, so it specifically sought these traits in candidates. Therefore, Claire was hired not only to work with the children, but also to guide the school community-including many children, parents, and longtime staff-toward a more authentic use of the Montessori Method.

\section{Data Collection}

Claire and I met for four interviews, participated in several parent-education events together, and communicated via e-mail. Additionally, I observed her working in her classroom one morning, and I shared my notes and opinions on the classroom environment with her, the head of school, and the board president.

\footnotetext{
${ }^{1}$ Pseudonyms are used throughout, and identifying details have been changed to preserve confidentiality and anonymity.
} 
The first interview with Claire took place at a coffee shop on a weekday evening, but subsequent meetings often turned into dinner. Most sessions generated roughly an hour of recorded interviews but often included additional social time together. Typically, our conversations began with questions like, "What has your experience been like at school recently?" Hoping to prompt experiential descriptions, I also asked her more probing questions such as, "What was it like when...?" and "What was X like for you?" Interviews were unstructured, but it was easy to stay close to the topic of Claire's experience in the school community. Though greater contextual information contributes to the overall findings and interpretations, the specific CDA of this report addresses one section of the second interview conducted in mid-December.

\section{Post-Reflexion Statement ${ }^{2}$}

Phenomenologists such as Husserl have in the past prescribed a need to bracket (meaning acknowledge and then set aside) the researcher's pre-understandings, assumptions, and beliefs during the analysis process (i.e., phenomenological reduction) (as cited in van Manen, 2014). However, others (Dahlberg, Dahlberg, \& Nyström, 2008; Vagle, 2014; van Manen, 2014) have suggested that these elements play an important role in the research process and should be included in the analysis. Dahlberg, Dahlberg, and Nyström (2008) pointed out that "researchers are also part of the same world as the one they are investigating. It is not possible for researchers to investigate a reality 'outside the window'" (p. 131).

Instead of bracketing, Vagle (2014) described a process of post-reflexing, in which researchers continuously reflect on their personal experiences while researching and analyzing the phenomenon. It is a process of constantly interrogating pre-understandings existent before, during, and even after data collection. For this reason, my own positionality within the school community, as well as my interpretations of the context, are important elements of the research process and analysis and are included in this report.

Researcher positionality. I became aware of and interested in the experience a newly hired Montessori teacher would have revitalizing Montessori practices through my position as a new board member. In addition to hiring a skilled Montessori teacher, the school board also sent out a call for a trained and experienced Montessorian to join the board of directors. I was excited to take this position on, and, about a month before Claire was hired, I was appointed the board's Montessori advisory chair. This provided me with firsthand insight into the board's intent to hire Claire based on her experience and knowledge. I was asked multiple times for my opinion during the hiring process, which included a casual phone interview between Claire and me. During that interview, I found Claire to be a passionate, highly knowledgeable, and dedicated Montessori teacher. I relayed this impression to the board members, and I wholeheartedly recommended they hire her-I may even have used the phrase "You'd be fools to pass her up!" As the school year began, I was asked to support Claire personally and professionally, as well as be available to field parent questions regarding authentic Montessori practices and changes made to the school's routine. I happily agreed to this role; I was excited to be a part of the transition and to support such a qualified teacher. Our interviews not only offered insight into the experience of a Montessori teacher in a leadership role, but also became an outlet for Claire to share her frustrations and seek advice, and for me to reconnect with my Montessori roots.

Contextual background. Claire described challenges with the staff and parents of the school far more often than any challenges she faced with her teaching or with the children. Her many years as an educator may have given her the knowledge and confidence she needed to understand, accept, and manage the busyness of a preschool classroom. However, multiple times during our conversations, Claire referred to a need to prove herself to the school community. It was a theme that came up repeatedly over the course of our year working together but was given extra attention during our second interview, conducted in the middle of December. At this meeting, Claire expressed frustration regarding the timing and demands of the school's holiday performance. At the same time, she was using this end-of-the-year event to promote and

${ }^{2}$ The term post-reflexion is specific to Vagle's (2014) post-intentional phenomenology. 
prove the importance of keeping children in the kindergarten program. Montessori developmental theory places significant importance on kindergarten, or what is referred to as the third year. During this time, children are not only supported in academic growth but also are given invaluable opportunities to develop socially as the older children and leaders in the community. Additionally, the mixed-age community creates many opportunities for peer teaching and modeling, a quality that fosters valued child independence (Lillard, 2005; Montessori 1967a). These features, along with other elements of a prepared Montessori classroom, are necessary for the development of a normalized environment, one in which children naturally display concentration on and cooperation in meaningful and purposeful activities (Montessori, 1967a). This idea was very new to most of the parents at the school; many had not even realized there was an option to keep their children in the program for kindergarten. In an effort to relay this message to parents, Claire and I both participated in a parent-education event focused on kindergarten, and she expanded her communication to parents on this subject. Claire was passionate about this issue, not only in terms of fostering optimal child development but also of seeing the older children as a critically important asset to her classroom. Promoting, marketing, and representing a Montessori education had become a substantial part of her job.

\section{Analysis and Findings}

Van Manen (2014) wrote that "phenomenology does not only describe what something is, it also explores what this phenomenon can mean by offering possible interpretations" (p. 390). Further, Vagle (2014) posited that analysis and findings regarding the researched phenomenon can be more fully explored when worked through together. For this reason, my analysis and findings are discussed jointly. Because I used Fairclough's three dimensions of analysis (discursive practice, text, and social practice) as my guiding analytical theory, I have divided the results into three corresponding sections.

\section{Discursive Practices}

The Discourses at play. Claire represented her work through the use of four different Discourses: Montessori, Day-to-Day Teaching, Personal Worth, and Social Reform. Montessori Discourse was identified by either direct reference to the Method or the use of language specific to Montessori teaching. The Day-to-Day Teaching Discourse consisted of descriptions of more traditional teaching activities and daily teacher duties. Social Reform Discourse focused primarily on social change made possible through a Montessori education. Finally, Personal Worth Discourse comprised the ways that Claire identified and described the need to prove herself. Table 1 shows specific examples of how these Discourses were portrayed.

Claire embodied these four Discourses in order to counteract a greater social and political Discourse that she and the school faced: School Marketization. Claire worked tirelessly to convince parents to keep their children in her classroom for their kindergarten year. It was assumed by Claire, as well as the parent board members that finances were not the greatest issue in this particular community; instead, the competition created by the public school lottery system generated significant stress and anxiety for many families. The preschool, located in a relatively affluent area of a large city, existed alongside many popular public, magnet, and charter elementary schools. The general belief of the parent community was that if children did not enroll in their neighborhood school or participate in the kindergarten lottery for other schools, they would lose their first-grade places in these high-quality public programs. While the facts about this system varied, rumors created enough concern that families were resistant to the idea of keeping their children in Claire's classroom for kindergarten. Therefore, Claire had to promote and market her program as a superior, and even transformative, school choice. 
Table 1

The Discourses at play

\begin{tabular}{|c|c|c|c|}
\hline $\begin{array}{l}\text { Montessori } \\
\text { Discourse }\end{array}$ & $\begin{array}{c}\text { Day-to-Day Teaching } \\
\text { Discourse }\end{array}$ & $\begin{array}{l}\text { Social Reform } \\
\text { Discourse }\end{array}$ & $\begin{array}{l}\text { Personal Worth } \\
\text { Discourse }\end{array}$ \\
\hline I believe in the Method. & $\begin{array}{l}\text { I had to really get on those } \\
\text { kids who weren't finishing } \\
\text { things. }\end{array}$ & $\begin{array}{l}\text { It's a huge investment of } \\
\text { your time. }\end{array}$ & I have to prove myself. \\
\hline $\begin{array}{l}\text { Seeing how happy and } \\
\text { engaged and motivated } \\
\text { and independent and } \\
\text { confident and eloquent and } \\
\text { sophisticated that their } \\
\text { children can become in the } \\
\text { environment, um, that is } \\
\text { serving their needs... }\end{array}$ & $\begin{array}{l}\text { You have to be in their } \\
\text { face about every one of } \\
\text { those little fires. And } \\
\text { there, it's, right now } \\
\text { there's a lot of them } \\
\text { because of the holidays, I } \\
\text { know that, and I know that } \\
\text { when we get to January, } \\
\text { it's gonna be a breath of } \\
\text { fresh air 'cause things } \\
\text { were better before. I } \\
\text { always know, like, from } \\
\text { Halloween until now, it's } \\
\text { downhill. }\end{array}$ & $\begin{array}{l}\text { It brings people together } \\
\text { when it's done well, and it } \\
\text { helps people see their } \\
\text { child as somebody who's } \\
\text { really capable of doing } \\
\text { things, and it helps people } \\
\text { to look at their } \\
\text { communication and how } \\
\text { they're communicating. }\end{array}$ & $\begin{array}{l}\text { I feel like I have to blow } \\
\text { them away with my } \\
\text { knowledge of child } \\
\text { development. }\end{array}$ \\
\hline $\begin{array}{l}\text { You know a lot of them } \\
\text { are very normalized, it's } \\
\text { going well, but the true } \\
\text { fact is, because of the way } \\
\text { this school does the } \\
\text { holiday show, I haven't } \\
\text { given, almost, I've almost } \\
\text { given no lessons in the } \\
\text { last, like, three weeks } \\
\text { because it required so } \\
\text { much. }\end{array}$ & & $\begin{array}{l}\text { I want to create that space } \\
\text { in the classroom, um, that } \\
\text { will ripple outward into } \\
\text { the parents' lives and the } \\
\text { lives of their children at } \\
\text { home and then in the } \\
\text { community. }\end{array}$ & $\begin{array}{l}\text { I have to be head and } \\
\text { shoulders above the } \\
\text { standard daycare model. } \\
\text { And so that's why I set a } \\
\text { high standard of myself } \\
\text { and, um, I hope that, you } \\
\text { know, that comes across, I } \\
\text { hope that the children feel } \\
\text { that, and that the parents } \\
\text { do. }\end{array}$ \\
\hline
\end{tabular}

As the Montessori leader in the school, Claire was responsible for creating a quality Montessori program for the children and educating parents on Montessori philosophy. The high-pressure existence of School Marketization Discourse, however, hindered her in accomplishing these goals. This challenge was further charged by Dr. Montessori's own discursive practice.

To segregate by age is one of the cruelest and most inhuman things one can do, and this is equally true for children. It breaks the bonds of social life, deprives it of nourishment. In most schools the sexes are first of all separated, then the ages each, more or less, in a different room. This is a fundamental mistake, which breeds a host of evils. It is an artificial isolation and impedes the development of the social sense. (Montessori, 1967a, p. 226)

Here, Dr. Montessori's commentary, the foremost influence on Montessori Discourse, is not lacking in opinion and represents a very clear belief system. Thus, Claire faced a dilemma created by the intersection of the School Marketization Discourse and her own internalized Montessori Discourse, comprising an impassioned knowledge (that mixed ages benefits development) and belief system (that mixed ages is socially correct). While Claire wanted to create and provide a truly authentic Montessori experience, she 
felt she could not do so without older children in the environment. Therefore, she felt unable to demonstrate the developmental and social possibilities fostered through a quality Montessori education to the parent community. This moment of crisis between multiple Discourses highlights her stress and uncertainty.

I want-I've, I believe in the Method because I've seen it, what it can do for a little community of children and parents. It brings people together when it's done well, and it helps people see their child as somebody who's really capable of doing things, and it helps people to look at their communication and how they're communicating. Um, and I believe at the heart of that, that, that is like a huge, a huge solution to all kinds of things going on in our world to make it a better place to be. So, I want to, um, I wanna, I wanna create that, I want to create that space in the classroom, um, that will ripple outward into the parents' lives and the lives of their children at home and then in the community. So to, to make that happen, they have to be there for three years!

Here, Claire's words create an interdiscursive chain (Fairclough, 1992) by using Montessori and Social Reform Discourses to support her beliefs. She believed the Montessori Method positively affected not just her students, but "all kinds of things going on in our world." However, she stated that this effect is achieved only when children participated in the program for all three years, including kindergarten. This statement depicts the dilemma caused by the School Marketization Discourse that permeated the school community and influenced many parents to move their children out of her program before kindergarten. More subtly, referring to her experiences and hopes reflected Personal Worth Discourse. While she did not take direct credit for creating such an awe-inspiring environment, she stated her beliefs based on what she had seen and experienced when "it's done well." She wanted to create this kind of environment and community in her new position, yet her ability to do so depended on parents continuing to enroll their children in her classroom.

\section{Text}

Who is responsible? Fairclough (1992) suggested that the ways producers produce texts signify their social identities, social relationships, and knowledge and belief (p. 76). Therefore, a textual microanalysis of the interview transcription shows how Claire characterized her experience, and herself, in her job.

The Montessori Discourse is the Discourse most interwoven throughout the excerpt, either by referring to Montessori education directly ("I have to prove Montessori to the people.") or using language specific to the Method ("It's like the end of the cycle."). However, there are some particular instances, specifically with word choice, where other Discourses override the Montessori Discourse. Word choices made by the producer of a text frequently have connections to wider social and cultural processes (Fairclough, 1992). Looking closely at how, when, and why Claire used certain keywords reveals competing Discourses within Claire herself.

In the first half of the interview, Claire used the noun kids three times, which is significant because many Montessori trainings avoid or even discourage the use of the word kid (kids are baby goats!) and promote the use of child and children instead. In the second half of this interview, when Claire was asked to expand on the idea of having to prove herself, she shifted her Discourse to primarily an authentic Montessori one and used only child and children when referring to her young students. Furthermore, when she did use kids, her words before and after expressed the demands of her job more candidly: "I had to really get on those kids who weren't finishing things, and encourage and entice them." In contrast, in the second half of the excerpt, Claire described how she wanted parents to see the children as "happy and engaged and motivated and independent and confident and sophisticated [as] their children can become in the environment." These excerpts reflect two different views, not only on how to refer to preschool-aged children, but also on their behavior and on the demands they place on their teacher. The dilemma between the Discourses of authentic Montessori and Day-to-Day Teaching exemplified how Claire struggled with maintaining her ideal Montessori identity. Her use of Montessori Discourse portrayed her identity as a highly passionate, dedicated, and knowledgeable Montessori teacher, one who legitimized the worth of 
paying for kindergarten. However, the Day-to-Day Teaching Discourse described challenges she faced in her job - challenges that tested her adherence to the image of the perfect Montessorian.

Claire's style, or way of identifying herself (Fairclough, 1992), was most frequently as a member of the group of preschoolers through the use of the pronoun we ("We need practice"; "We are moving up"). She distanced herself from the parents through the use of $I$ and they statements such as, "I have to blow them away with my knowledge of child development" and "get them to wanna pay for kindergarten." Claire described how she positioned herself within the school community: "I know that when we [the community of preschoolers] come back, [the parents will] have had this time to simmer in [the level of work the children have produced]."

Claire saw herself with the children, favoring their place and role within the school community. By doing so, she also gave the children the responsibility of helping to prove Montessori to their parents, effectively sharing the weight of this job with her preschool class.

I have to prove Montessori to the people. I have to prove it to the kids that, um, the reason we're not taking home work every day is because it's gonna feel awesome when you put all this stuff together that you've collected. And then today we just were wrapping up all of their books and things that they've made to give a present to their family.

After commenting about parents having time to "simmer" in their children's work, she elaborated that "the parents will have had the time to process: "Wow, look what those kids can do when they're motivated!"” Thus, the ability to prove Montessori to the parent community depended not only on kindergarten enrollment, but also on the children's willingness and ability to share their school endeavors with their parents. This dilemma prompts the question: Which of these elements - kindergarten enrollment or children relaying their school experiences to parents - is more important? Without older children in the classroom, Claire felt that she could not create the optimal Montessori learning environment for all students. However, if children did not share their work and development with their parents, the families would not see what makes Montessori education worth considering in the first place. Though Claire repeatedly referred directly to her task of proving Montessori, significant responsibility, perhaps equal to her own, was placed on the children's ability to do this as well.

Claire defended her pedagogical decisions with reflective statements such as "I feel," "In my experience," and "I've seen." These phrases used multiple forms of authority to legitimize her beliefs and practices. For example, in the following quote, Claire used the phrase "in my experience" to invoke personal, expert, and role model authority (van Leeuwen, 2007).

Now it's like the end of the cycle where they can see how it, it takes a while for them to see the richness that then now my, in my experience when we do it this way, uh, they're just like, it creates a boost to their work.

The parents - "they"-were unaware of the rich and advanced work children in a Montessori environment are capable of. Claire used her experiences to emphasize her expertise and expert authority, one form of authorization (authority vested in an individual regarding the legitimation of a specific subject) a part of the categories of legitimation (van Leeuwen, 2007). Using experience and knowledge to guide her decisions, she also positioned herself as a role model - a wise and skillful teacher whom others could confidently follow (i.e., role model authority). Finally, Claire knew that she was hired to lead the community in the development and refinement of Montessori best practices. Thus she took up her personal authority as a teacher-leader - an authority granted by status or role within an institution (van Leeuwen, 2007) - to guide the decisions of the greater community: "When we do it this way."

However, these authoritative, legitimizing statements contrast with other "I" statements, such as "I have to" and "I wanna create that." Despite her authority, Claire felt a need to justify the decisions she was tasked with making and carrying out by herself, placing her in a position that can be lonely, emotional, and uncertain. Just as Claire felt conflicted between representing the ideal and the reality of her work, she 
juggled seeing herself as a member of a group working together to impress parents with being in charge of creating a highly authentic Montessori learning environment all by herself.

\section{Social Practice}

Resisting and embodying ideology. Claire was hired to teach the children in an authentic Montessori way - she was given a job to do in the classroom with children: "I have to prove myself, I have to prove Montessori to the people, I have to prove it to the kids." Yet this excerpt shows that her work expanded beyond the classroom walls and into another belief- and relationship-based social system. Notably, in this statement Claire first declared the need to prove herself. As a newcomer to the school, Claire had to promote not only Montessori philosophy but also herself as an important member of the school community, building relationships to garner support. Claire faced this challenge directly; however, without those connections, it was difficult for her to prove the value of a Montessori education.

When asked to elaborate on needing to prove herself, she revealed - this time through a highly personal lens - another dilemma between the ideal (Montessori and Social Reform Discourses) and the reality (Day-to-Day Teaching and Personal Worth Discourses). Claire's demands on herself were divided between her desire to "blow [parents] away with [her] knowledge of child development" and her resistance to a feeling that she must ultimately change herself.

[Montessori is] a lifelong investment for your child. So, to do that, I just feel like I have to be head and shoulders above the standard daycare model. And so that's why I set a high standard of myself and, um, I hope that, you know, that comes across-I hope that the children feel that, and that the parents do. However, there are certain things I'm not willing to do-you know, like, I've, um, you know, there's certain cultural things that, you know, like, I'm not gonna be nice, I mean I'll be, I'll be kind and professional, but I'm not gonna be fake and that, that's just like a personal choice, and so, um, I have to sometimes make up for [laughs]. I feel like I have to sometimes make up for certain parts of my personality of just who I am, that maybe to some people might seem abrasive or, you know, whatever. So, um, I wanna be able to be myself completely and sometimes I have to make up for that [laughs] a little bit too!

Here, the tension created between Claire's desire to impress parents and her resistance to changing herself, or to succumbing to the ideal image of a preschool teacher, is obvious. Ideology is a social construct possessing great power (Swartz, 1997). Bourdieu (as cited in Swartz, 1997) referred to ideology as a form of "symbolic violence" (p. 89) that creates expected adaptations to the social world influenced by economic and political power yet disguised as everyday ways and actions. Similarly, Fairclough (1992) wrote that "the discursive constitution of society does not emanate from a free play of ideas in people's heads but from a social practice which is firmly rooted in and oriented to real, material social structures" (p. 66). Social constitution and reproduction are based in ideology that has become rooted in tangible social structures. In this case, the ideal preschool teacher is one who embodies an age-old image of a soft, passive, and compliant individual (arguably a woman). Claire viewed herself as quite different from, if not the opposite of, this ideal image. She would be neither fake nor shallow and simple. She felt her personality could be seen as abrasive instead of gentle and serene. Even kindness and professionalism were incompatible with the preferred "nice," more casual, and laid-back preschool teacher identity.

Taking up an analysis on the broader Discourse of how a preschool teacher should look and act could be highly enlightening. However, for the purpose of containing this paper, I will continue to focus on Claire's specific experience and social relations. Claire resisted this preschool teacher ideology but also felt she had to compensate for what she lacked in other ways (a "good-enough compromise"). She hoped to do this by positively affecting the children and, once again, depending on them to demonstrate her worth to their families. 
Claire: So I feel like I have to prove in other ways that, like, my reasons for doing these other, doing it this way is....

Author: And prove by the children really showing, exhibiting....

Claire: Yeah.

Author: The greatness of....

Claire: Yeah! Loving school. Just loving to be there. Yeah.

Two important conclusions can be drawn from this final excerpt, which was in fact the end of the interview. Though Claire's words suggested she opposed fulfilling an image of the ideal preschool teacher, she was working to embody that of the ideal Montessori teacher (Malm, 2004). To do this, she had to "talk the right talk, walk the right walk, [and] behave as if [she] believe[d] the right things" (Gee, 2014, p. 24). Claire had "reasons," the knowledge and beliefs, necessary for "doing it this way," or teaching according to Montessori pedagogy. She wanted to "blow [the parents] away with [her] knowledge of child development," or talk the right talk. She intended to walk the right walk by "[creating] that space in the classroom that will ripple outward into the parents' lives and the lives of their children at home and then in the community." Having to prove herself was coupled with having to prove the value of Montessori education because its system of knowledge and beliefs was a deep part of her personal identity.

Finally, by using the evaluative word "love," Claire referenced the value system of love versus hate that placed a moral value on her decisions. Moral evaluation legitimized the choices she made as a Montessori teacher-leader, including her reasons to not change her personality (van Leeuwen, 2007). Additionally, her desire or belief that children experiencing the Montessori Method will love school is supported by significant Montessori authority. Dr. Montessori herself wrote extensively about her observations of children loving school as she developed her Method of education.

Our children are notably different from those in ordinary schools. They have the calm look of happy individuals and the ease of those who are masters of their own actions.... They give the impression of being remarkable little men and women.... This is what makes us call our little ones happy and wonderful children. (Montessori, 1967b, p. 321)

Furthermore, Dr. Montessori used these child characteristics to promote her Method to the world, describing experiences such as "The Children's House seems to have a spiritual influence on everyone," and "[The children] represent a childhood that is more advanced than was our own" (Montessori, 1967b, p. 321). While Claire wanted the children to love school, she further hoped they would actively display that love to their parents, just as was done in the past. Love of school would have legitimized her own value and the value of Montessori education.

Fairclough (1992) defined hegemony in discourse analysis as the "constructing of alliances, and integrating rather than simply dominating subordinate classes, through concessions or through ideological means, to win their consent" (p. 92). In this study, hegemony is addressed with Montessori Discourselegitimized ideology. Claire's strategy is hegemonic in that she sought to rally support by creating and displaying the effects of an ideal Montessori education. She wanted to transform parents' educational knowledge and belief systems - win their consent and construct an alliance-by replacing one ideology with another. Children showing that they loved school, or more specifically showing that they simply loved to be at school, was the way to do this.

\section{Discussion and Implications}

Claire is a passionate Montessori teacher with years of experience that guide and support her teaching strategies and decisions. She is highly knowledgeable of Montessori theory and curriculum and believes the work she does can change the world. However, this analysis illuminated moments in which she experienced dilemmas frequently caused by conflicts between her identity as a Montessorian and other social identities and Discourses. Claire's own words showed that multiple Discourses worked together 
(Montessori and Social Reform Discourses) or caused uncertainty about her teaching practice, her ability to represent the true Montessori teacher social identity, and her own personality (Day-to-Day Teaching and Personal Worth Discourses).

Prominent Montessori organizations' depictions of a Montessori teacher primarily focus on duties related to child development, classroom atmosphere, and bettering the world (Association Montessori Internationale/USA [AMI/USA], n.d.; American Montessori Society [AMS], n.d.; North American Montessori Teachers' Association [NAMTA], n.d.). A Montessori educator respects children, assists their development through engaging activities, and creates a calm environment (AMI/USA, n.d.). A Montessori teacher fosters collaboration and is a creative resource for children to learn from (AMS, n.d.). Finally, a Montessori teacher is one who not only wants to work with children, but also makes a difference in the world, is emotionally independent, and possesses a "zest for life" (NAMTA, n.d.). While these descriptions exist to market the career and entice prospective teachers, their words may have a greater effect. Ngo (2012) has suggested that, "through repeated use and circulation, some D/discourses become so established that they become 'natural' and conceal the existence of competing, alternative discourses" (p. 47). Perhaps established Discourses such as the ones listed above have concealed the alternative Discourses that are part of a Montessori teacher's lived experience, Discourses that affect a Montessori teacher's identity.

This analysis showed that Claire characterized her experience of proving Montessori philosophy through multiple discursive relationships, identities and self-representations, and social practices. Yet such Discourses are not acknowledged in such Montessori spaces as websites and literature. Was Claire emotionally independent? She described her job as one given to her and her alone. However, this analysis discovered that she was, in many ways, dependent on the children and parents believing that she truly embodied the social identity of the Montessori teacher. Was it Claire's responsibility to create an environment that met all of the children's developmental needs? In fact, Claire was hired to do exactly that; however, she faced situations beyond her control that challenged her creation of the ideal, normalized Montessori environment. Was the collaboration she was tasked with developing focused only within the preschool environment? This analysis revealed that Claire depended on the collaboration, acceptance by the school community, and alliances formed among herself, the children, and parents. Without them, she could not prove her value, nor could she prove the value of a Montessori education.

Montessori Discourse prescribes a social identity that can be challenged by many elements of today's educational social world. Because being an authentic Montessori teacher requires commitment to a system of knowledge and beliefs that contributes to the development of one's social and personal identity, the dilemmas arising from these conflicts can have deeply personal effects. Claire's words depicted an uncertainty composed of passion and frustration about her ability to fulfill the expectations of a Montessori teacher's social and personal identity. Further research is needed on how evolving social demands, parent and school expectations, and educational policies affect Montessori teachers and curriculum. This analysis and future research can be helpful in finding ways to meet these demands while preserving the curriculum. However, it is equally important to generate awareness - and acceptance - of the inner conflicts these requirements may produce for teachers and to offer the support they need to work with and through the uncertainty of this position.

Dr. Montessori (1991) wrote, "The task of the new teacher is a hard one, and I try to remember every principle that can help her" (p. 108). By better understanding today's Montessori teacher experience, we can develop the principles needed to train, guide, and help educators as they face both personal and social challenges in their role. Supporting teachers in this holistic way may enhance the greater social world's understanding, recognition, and value of an authentic Montessori education.

\section{AUTHOR INFORMATION}

Olivia Christensen is a doctoral candidate at the University of Minnesota in the department of Curriculum and Instruction and is the Sr. Ann Harvey Visiting Professor for St. Catherine University's Advanced Montessori Programs. She can be reached at otchristensen@stkate.edu. 


\section{References}

American Montessori Society. (n.d.). Montessori teachers. Retrieved from http://amshq.org/MontessoriEducation/Introduction-to-Montessori/Montessori-Teachers

Association Montessori Internationale/USA. (n.d.). The Montessori teacher. Retrieved from http://amiusa.org/the-montessori-teacher/

Barker, C. (2012). Cultural Studies. Thousand Oaks, CA: SAGE Publications.

Bartik, T. J. (2014). From preschool to prosperity: The economic payoff to early childhood education. MI: W. E. Upjohn Institute for Employment Research. doi: 10.17848/pol2015-017

Copple, C., \& Bredekamp, S. (Eds.). (2009). Developmentally appropriate practice in early childhood programs serving children from birth through age 8. Washington, DC: National Association for the Education of Young Children.

Cossentino, J. (2009). Culture, craft \& coherence: The unexpected vitality of Montessori teacher training. Journal of Teacher Education, 60(5), 520-527. doi: 10.1177/0022487109344593

Cuban, L. (1992). Managing dilemmas with building professional communities. Educational Researcher, 2l(1), 4-11.

Dahlberg, K., Dahlberg, H., \& Nyström, M. (2008). Reflective lifeworld research. Lund, Sweden: Studentlitteratur AB.

Fairclough, N. (1992). Discourse and social change. Cambridge, England: Polity Press.

Floden, R., \& Buchmann, M. (1993). Between routines and anarchy: Preparing teacher for uncertainty. Oxford Review of Education, 19(3), 373-382. doi: 10.1080/0305498930190308

Gee, J. P. (2014). An introduction to discourse analysis: Theory and method. New York, NY: Routledge.

Graue, E., Kroeger, J., \& Prager, D. (2001). A Bakhtinian analysis of particular home-school relations. American Educational Research Journal, 38(3), 467-498. doi: 10.3102/00028312038003467

Hall-Kenyon, K. M., Bullough, R. V., MacKay, K. L., \& Marshall, E. E. (2014). Preschool teacher wellbeing: A review of the literature. Early Childhood Education, 42(3), 153-162.

Helsing, D. (2007). Regarding uncertainty in teachers and teaching. Teaching and Teacher Education, 23(8), 1317-1333. doi:10.1016/j.tate.2006.06.007

Kilgallon, P., Maloney, C., \& Lock, G. (2008). Early childhood teachers coping with educational change. Australian Journal of Early Childhood, 33(1), 23-29.

Lampert, M. (1985). How do teachers manage to teach? Perspectives on problems in practice. Harvard Educational Review, 55(2), 178-194.

doi: http://dx.doi.org/10.17763/haer.55.2.56142234616x4352

Lillard, A. (2005). Montessori: The science behind the genius. New York, NY: Oxford University Press.

Malm, B. (2004). Constructing professional identities: Montessori teachers' voices and visions. Scandinavian Journal of Educational Research, 48(4), 397-412. doi: 10.1080/0031383042000245799

Montessori, M. (1967a). The absorbent mind. New York, NY: Dell Publishing Co.

Montessori, M. (1967b). The discovery of the child. New York, NY: Ballantine Books.

Montessori, M. (1991). The child in the family. Madras, India: Kalakshetra Publications.

Ngo, B. (2012). Constructing immigrant adolescent identities: Exploring the "magical Property" of discourses. In M. Vagle (Ed.), Not a stage! A critical re-conception of young adolescent education (pp. 45-55). New York, NY: Peter Lang Publishing.

North American Montessori Teachers' Association. (n.d.). A career in Montessori education. Retrieved from http://www.montessori-namta.org/Careers

Sumsion, J. (2002). Becoming, being and unbecoming an early childhood educator: A phenomenological case study of teacher attrition. Teaching and Teacher Education, 18(7), 869-885. doi: $10.1016 / \mathrm{S} 0742-051 \mathrm{X}(02) 00048-3$ 
Swartz, D. (1997). Culture and power, the sociology of Pierre Bourdieu. Chicago: The University of Chicago Press.

Vagle, M. D. (2014). Crafting phenomenological research. Thousand Oaks, CA: Left Coast Press.

van Leeuwen, T. (2007). Legitimation in discourse and communication. Discourse \& Communication, 1(1), 91-112. doi: 10.1177/1750481307071986

van Manen, M. (2014). Phenomenology of practice: Meaning-giving methods in phenomenological research and writing. Thousand Oaks, CA: Left Coast Press. 